\title{
Knowledge on and intake of Folic acid supplementation in pregnant women in Denmark
}

\author{
Mikkel Mylius Rasmussen ${ }^{1 *}$, Dorte Clemmensen², Claus Mosdal ${ }^{2}$ \\ From 54th Annual Meeting of the Society for Research into Hydrocephalus and Spina Bifida \\ Vancouver, Canada. 7-10 July 2010
}

\section{Background}

Folic acid (FA) deficiency is related to neural tube defects (NTD). In a non risk pregnancy The Danish National Board of Health recommends a FA supplementation from planned pregnancy until 3 month after conception. We looked into pregnant women's knowledge about and actual supplementation of FA and related this to education, number of pregnancies and age.

\section{Materials and methods}

Eighty four consecutive pregnant women with a midwife consultation were included from the 25th - 28th of August 2008. All filled out a unified questionnaire.

\section{Results}

$82 \%$ had knowledge of FA supplementation and $89 \%$ had a FA supplementation. 51\% followed national recommendations. We found statistically significant correlation between higher educational level and knowledge about FA supplementation, actual supplementation of FA and FA supplementation in correlation with national recommendations. No statistical relations were found between number of pregnancies or age and FA related parameters. Family, friends, general practitioner (GP) and the internet were main information sources.

\section{Conclusions}

Correct FA supplementation is quite low, correspondingly knowledge about and supplementation of FA is fairly high. Further intervention is necessary to increase correct FA supplementation. Women with low educational level, perhaps as an indicator for low socioeconomic status seem as a group of interest. Multiple

\footnotetext{
* Correspondence: mikkelmylius@gmail.com

'Department of Neurosurgery, Aalborg Hospital, Aarhus University Hospital

Hobrovej 18-22, Posboks 365, 9100 Aalborg, Denmark

Full list of author information is available at the end of the article
}

pregnancies or higher age cannot be seen as indicators for a higher information level. Information to the pregnant women incorporating family, friends, GP or the internet is suggested.

\section{Author details}

'Department of Neurosurgery, Aalborg Hospital, Aarhus University Hospital Hobrovej 18-22, Posboks 365, 9100 Aalborg, Denmark. ²Department of Neurosurgery, Aarhus Hospital, Aarhus University Hospital Nørrebrogade 44, 8000 Århus C, Denmark.

Published: 15 December 2010

doi:10.1186/1743-8454-7-S1-S25

Cite this article as: Rasmussen et al:: Knowledge on and intake of Folic acid supplementation in pregnant women in Denmark. Cerebrospinal Fluid Research 2010 7(Suppl 1):S25.
Submit your next manuscript to BioMed Central and take full advantage of:

- Convenient online submission

- Thorough peer review

- No space constraints or color figure charges

- Immediate publication on acceptance

- Inclusion in PubMed, CAS, Scopus and Google Scholar

- Research which is freely available for redistribution

Submit your manuscript at www.biomedcentral.com/submit
() Bïomed Central
C Biomed Central

(ㄷ) 2010 Rasmussen et al; licensee BioMed Central Ltd. This is an open access article distributed under the terms of the Creative Commons Attribution License (http://creativecommons.org/licenses/by/2.0), which permits unrestricted use, distribution, and reproduction in any medium, provided the original work is properly cited. 